\title{
The Adjustment and Effects of Vocabulary Teaching Strategies in Flipped Classroom
}

\author{
Hongwei Zhang, Jie Li, Liping Jiao, Weilian Ma, Chen Guan \\ Foreign Languages Department, Baoding University, Baoding, China \\ Email: huosiqi2005@126.com
}

Received 20 July 2016; accepted 26 August 2016; published 29 August 2016

Copyright (C) 2016 by authors and Scientific Research Publishing Inc.

This work is licensed under the Creative Commons Attribution International License (CC BY). http://creativecommons.org/licenses/by/4.0/

c) (i) Open Access

\begin{abstract}
The importance of vocabulary teaching is self-evident. Yet, the present English vocabulary teaching model is still far more traditional than modern because of the inadequacy of education revolution. The flipped classroom teaching model brings a new horizon to the field of vocabulary teaching. This paper takes the freshmen in the English department of a college in northern part of China as the main body of research analyzes the results of the experimental vocabulary teaching and gets the conclusion that the flipped classroom teaching model promotes English vocabulary teaching outcomes.
\end{abstract}

\section{Keywords}

Vocabulary Teaching, Flipped Classroom, Adjustment

\section{Introduction}

Vocabulary, as the foundation of any language, holds an important rank in the linguistic systems. Wilkins points out: "Without grammar, very little can be conveyed; without vocabulary, nothing can be conveyed" (Wilkins, 1972). Vocabulary learning is vital to foreign language acquisition. However, the effectiveness of vocabulary teaching has long since been far from satisfying. And research shows that the vocabulary level of English majors at college is not optimistic at present. This is partly due to the fact that many English teachers deal with English vocabulary teaching in the traditional way, which has many problems. For example, it costs a great deal of time of the teacher to explain and analyze the usages of the words, usually in isolation. The class is teacher-centered and there is no activity in class to help the students to internalize the knowledge of the new words. The students cannot use the vocabulary flexibly and they feel bored of the traditional teaching model. Thus, the efficiency of vocabulary learning is rather low.

Some of the above limitations are likely to be overcome in a new model of classroom teaching - the flipped 
classroom model of vocabulary teaching.

The flipped classroom model is becoming more and more popular since Eric Mazur has developed his instructional strategy Peer Instruction in the 1990s. One of the eminent features of the flipped classroom is that it reconstructs the teaching process and uses teaching videos, and/or other forms of material to teach the basic knowledge before classroom instruction instead of merely in-class teaching, therefore it contributes to timesaving for in-class group discussion, individual tutoring, etc. Vocabulary teaching in the flipped classroom can also provide the students with all kinds of activities to internalize the knowledge in class, which may help arouse students' learning interest, and at the same time, the learning outcome.

However, the flipped classroom teaching strategy is not without limitations and criticism. Some scholars such as Lents \& Cifuentes (2009) and Strayer (2012) list their reasons for not using this new strategy. The question naturally arises: Is the flipped classroom vocabulary teaching strategy more effective compared with the traditional vocabulary teaching models? If so, are there any problems to be settled to improve this new teaching strategy? Bearing these questions in mind, the authors of the paper designed the following research to find out the effects of vocabulary teaching in flipped classroom.

\section{Literature Review}

As a part of language teaching, vocabulary teaching modes has changed over time. Vocabulary teaching in each period has its own characteristics.

\subsection{Some Conventional Vocabulary Teaching Methods}

The grammar translation method was first introduced to modern languages in public schools in Prussia at the end of the eighteen century. This method prevailed in Europe from 1840 to 1940, which was the main method of foreign language teaching for a long time. Its principle characteristics about vocabulary teaching include reading text based vocabulary selection, bilingual explanation of vocabulary items etc. (Richards, 2000). In a classroom guided by this method, students are encouraged to use bilingual vocabulary. A usual consequence of this method is that students cannot use the words independently for the purpose of communication. With the development of other methods and approaches, grammar translation method has been replaced gradually.

The direct method was the best known of several "natural" methods introduced towards the end of the 19th century. Its name came from the priority of relating meaning directly with the target language without the step of translation. The principle characteristics about vocabulary teaching of this method include exclusive use of the target language in classroom, teaching of everyday vocabulary through demonstration and abstract vocabulary association of ideas, and the stress of pronunciation (Richards, 2000).

The direct method started in the 19th century, is a product of the foreign language teaching movement in the west Europe. It can effectively improve the students' ability of English listening and speaking. But its main drawback lies in its inefficiency in explaining some complex and abstract concepts.

The communicative approach emphasizes that the goal of language learning is communicative competence. Students are given tasks to accomplish using vocabulary, instead of studying the vocabulary. Its main characteristic is that we must pay attention to the meaning of vocabulary and we must master the vocabulary to communicate. The classroom instruction is student-centered education, in which teachers play the role of a facilitator, helper and a consultant. The communicative method was introduced into the traditional classes soon and has been widely expanded since its appearance. However, the communicative approach emphasizes vocabulary fluency but neglect accuracy of vocabulary, which is ineffective in vocabulary teaching. In the period of communicative approach, vocabulary teaching did not get enough attention.

\subsection{The Flipped Classroom Model and Researches on It}

Flipped classroom, as a revolution of the teaching methods, was pioneered by two American teachers John Bergmann and Aaron Sams. They combined real-time explanation and demonstration of PPT videos and put them on the Internet, which has aroused public attention. Since then, the flipped classroom model has been popularized at all American colleges and universities generally. In 2011, New York Times and Global Times published articles about Flipped Classroom and called it a great reform of classroom teaching models.

There are more and more related researches about the flipped classroom teaching model. Song (2014) illu- 
strated the procedure of English teaching in flipped classroom in detail, which provides us with a new method of English teaching. Chen (2014) introduced her procedure of the flipped classroom teaching model and pointed out the advantages and disadvantages of flipped classroom, which helps us understand the flipped classroom better. However, it does not involve vocabulary teaching under the flipped classroom model. Zhang (2009) introduced many vocabulary teaching strategies in detail, which has great significance to vocabulary teaching. However, it focuses more on the teaching, ignoring the feedbacks of the students. And it does not involve the feasibility of these strategies and it does not explore the effects of vocabulary teaching strategies.

\section{Methodology}

In order to find the effects of vocabulary teaching in the flipped classroom, the authors selected Unit 2 "say yes" in the Integrated Skills of English Book 2 as the teaching material, and did experimental teaching. The students in class A were taught with the flipped classroom model and the students of class B in the traditional way.

\subsection{Teaching Design}

In this part, the experimental teaching design would be introduced in details.

\subsubsection{Vocabulary Teaching in the Traditional Classroom}

In the traditional classroom, the teacher used traditional English vocabulary teaching method, and gave detailed analysis of the meaning and usages of the words and phrases, which lasted for about 2 teaching hours. The classroom was teacher-centered, and the cultivation of students' communication competence was ignored. The teaching of vocabulary without any interactive activities made students increasingly bored.

After class, the students were required to finish the exercises behind the text.

\subsubsection{Vocabulary Teaching in the Flipped Classroom}

Vocabulary teaching in the flipped classroom includes two phases: pre-class learning of the basic knowledge on the words and phrases, and in-class activities which improves both the internalization of the knowledge and the real-time communicative abilities.

Before class, the teachers prepared video lectures on the vocabulary in Unit 2 which lasted for about 15 minutes and sent them to the students. Students learnt the teaching videos and worked in pairs to finish writing a short story with the newly learned words and phrases before coming to the class. The students needed to use at least 10 words in the glossary of Unit 2 when making up the story. This cost the students no more than half an hour (according to the interview).

In class, the teacher first spent 5 minutes on the questions students got in video-watching before the class. Then a word relay race game was held, which cost 20 minutes. This game is more than interesting and of great importance. It can strengthen the students' mastery of the basic knowledge of the vocabulary. In addition, it can strengthen students' understanding of the words in intense competition environment and enhance the students' spirit of teamwork and their sense of group honor. In the latter part of the class, the students shared their stories with other pairs. Discussions were encouraged in both mistake-checking and writing appreciation. The teacher walked around to help with difficulties and unsure usages of the words. If the word relay race game was to help memorize the basic information of the words, the story-making assignment then was to test the students' ability in using the words in free imagined situations. The students tried, sometimes failed, but anyway learned. Besides, in this process, the teacher could get feedback to make improvements in teaching.

After class, the students were required to finish the exercises behind the text, just like in the traditional way of teaching.

So, to summarize, the students spent 2 class hours on vocabulary learning in both the traditional mode of vocabulary teaching and the flipped classroom mode of vocabulary teaching (including both the pre-class learning and the in-class activities). And the post-class exercises are the same to both of the two classes.

\subsection{Participants}

The participants of the research were the freshmen English majors of class A and class B of the foreign languages department of a university in the northern part of China. There are 30 girls and 2 boys in class A while 
29 girls and 3 boys in class B. The general English level of the two classes was roughly equal according to the college entrance examination score and the final examination score in the first semester. Besides, they are all interested in Internet and cell phone, which enables them to get all sorts of information and learning materials. But, the students of class A were trained to use the college Internet learning platform, where the students could download the micro-lectures and other learning materials. And the students of Class A had computers and internet service in the dormitory.

\subsection{Instruments}

The research instruments included test papers and interviews. The tests were designed to get the direct results of vocabulary teaching. And the interview was designed to get to know the attitudes of the students towards the two different vocabulary teaching models.

\subsubsection{Test}

Two test papers on the vocabulary of Unit 2 were designed. The first test was given right after the vocabulary learning activities in the class and the second test was carried out one week later, when the exercises behind the text were finished and there was already a certain period of time after the vocabulary learning, in order to know about the retention of learning.

Altogether, 70 items are designed in the first test, aiming at the following two aspects:

1) The mastery of the basic knowledge of the vocabulary. Forty questions are included, such as phrase translation and blank-filling.

2) The correct usage of the vocabulary. Thirty questions are included, such as sentence translation and making new sentences.

The total score of the first test paper was 100. And the test limitation was 45 minutes, which allowed most of the students to finish the test items.

The second test was to write a story with at least ten target words. This test was to measure students' comprehensive ability in using the learned vocabulary. The total score of the second test was 10 and it was assigned to finish after class.

\subsubsection{Interview}

Through careful analysis of the first test, the researchers did the interview with 12 students of different levels (6 students from each class) after the first test. Fifteen questions were included in the interview with class A students. Five questions were about the learning situations of the students in the flipped classroom. Four questions were about the attitudes of the students towards vocabulary teaching in the flipped classroom. And six questions were about the suggestions of students towards vocabulary teaching in the flipped classroom. Eleven questions are included in the interview with class B students. Six questions were about the learning situation in the traditional classroom. Three questions were about the attitude of the students toward vocabulary teaching in traditional classroom. And two questions were about the suggestions of the students towards vocabulary teaching in the traditional classroom.

\subsection{Data Collection}

In this research, 64 students from both Class A and Class B took the first test. All the 32 students in class A handed in the test paper and 25 out of 32 students in class B handed in the test paper. The researchers marked the test papers then.

And in order to find out the main problems in vocabulary teaching and learning, an interview with 12 students of different levels ( 6 students for each class) was also carried out when the first test was done. The students were interviewed on the playground individually. One week after the first test, 18 students of different levels (9 students for each class) were given the second test.

\section{Results and Discussions}

In this part the researcher describes and discusses the results of the test paper, which will present us whether there are any significantly different effects between the two teaching modes. Then the researcher describes the 
results and analysis of the interview.

\subsection{The Results of the Test Papers and the Discussions}

We mainly report the results of the previous tests. First, some basic descriptive statistics are displayed to compare the total scores of the two tests. The results of the first test are displayed in Table 1 and Table 2. The results of the second test are displayed in Table 3. The results of the two tests reflect clearly on the efficiency of vocabulary teaching in flipped classroom.

In Table 1, the data shows clearly that 5 students in class A are in the grade section of $90-80 ; 11$ students in class A are in the grade section of $80-70$, while only 1 student in class B is in this section; 6 students in class A are in the grade section of $70-60$, and it is the same with class B; 7 students in class A are in the grade section of $60-50$, while 10 students in class B are in the same section; 3 students in class A are in the grade section of 50 - 40, while there are 7 students in class B; however, 3 students in class B got less than 40 points and nobody in class A. The data above can clearly tell us that the score of class A is much higher than class B, namely the students who learn vocabulary in flipped classroom get a higher score than that of the students in traditional classroom. Besides, there are totally 16 students whose scores are above than 70 points in class A, while only one student in class B. And 22 students, more than a half of class A, passed the test, while only 7 students in class B passed the test. Furthermore, 10 students in class A failed the exam while 20 students, more than a half of the class B, failed the test. The data above reveals a serious imbalance in the two classes. However, the students of the two classes both said that the test paper is not difficult at all in the interview. Before the first test the teacher of class A only spent 90 minutes to teach the vocabulary in class and the teacher of class B spent 135 minutes to teach the same vocabulary in class. However, the students of class A spend 90 minutes to prepare the vocabulary before the class and the students of class B spend 110 minutes to prepare the same vocabulary, which also implies that vocabulary teaching in flipped classroom is more effective than vocabulary teaching in traditional classroom. Flipped classroom provides a new way of transmitting knowledge before class, and internalizing knowledge in class, which is more than effective.

Table 1. The results of the two classes for the first test.

\begin{tabular}{ccc}
\hline Grade Section & Number of Students in Class A & Number of Students in Class B \\
\hline $90-80$ & 5 & 0 \\
$80-70$ & 11 & 6 \\
$70-60$ & 6 & 10 \\
$60-50$ & 7 & 7 \\
$50-40$ & 3 & 3 \\
\hline
\end{tabular}

Table 2. The comparison of the two classes for the first test.

\begin{tabular}{cccc}
\hline Score & Class A & Class B & Gap \\
\hline The highest & 88 & 71 & 17 \\
The lowest & 41 & 23 & 18 \\
Average & 65.934 & 51.111 & 14.823 \\
\hline
\end{tabular}

Table 3. The result of the second test.

\begin{tabular}{cccc}
\hline Score & Class A & Class B & Gap \\
\hline The highest & 10 & 9 & 1 \\
The lowest & 6 & 3 & 3 \\
Average & 8.1 & 7 & 1.1 \\
\hline
\end{tabular}


In Table 2, we can see that the highest score of class A is 88 points which is 17 points higher than that in class B. And the lowest score of class A is 41 points which is 18 points higher than that in class B. Besides, the average score of class A is 65.934 points and the average score of class B is 51.111 points, which reveals a big gap in the two classes. The comparison of the two classes also shows that vocabulary teaching in flipped classroom is more effective than vocabulary teaching in traditional classroom. And the results of the first test reflect the fact that vocabulary teaching in flipped classroom can help students improve their learning achievements. Flipped classroom makes vocabulary teaching effective, which is a great improvement in vocabulary teaching.

In Table 3, the data shows that the highest score of class A is 10 points and that of class B is 9 points. The lowest mark of class A is 6 points and that of class B is 3 points. And the average score of class A is 8.1 points and that of class B is 7 points, which reveals a significant difference of the two classes. Before the second test, the teacher of the flipped classroom totally spent 135 minutes in vocabulary teaching, while the teacher of traditional classroom spent 225 minutes in vocabulary teaching. However, the result of the second test is still as the same as the first test. Although the teacher of traditional classroom spent much more time on vocabulary teaching, the students had no interest and were tired of it, which made the learning of vocabulary ineffective and the result not satisfactory. While the teacher of flipped classroom spent fewer time, compared with the teacher of traditional classroom, and got a better result. Both the students and the teacher of class A said vocabulary teaching in flipped classroom is effective and interesting. Under the model of flipped classroom, the students can watch the teaching video over and over again, which is time-saving and flexible. And students can get more chance to interact with the teacher through all the activities in class, which can really help them internalize the vocabulary. However, both the students and the teacher of class B said although they spent quite a lot of time in vocabulary teaching and learning, the vocabulary learning effect is still not satisfactory. Therefore, from the results of the test we can know that flipped classroom is both effective and interesting which can save a lot of time and make the students fall in love with learning vocabulary. In addition, vocabulary teaching in flipped classroom can help students achieve a good result in vocabulary learning. In short, teaching vocabulary in flipped classroom has lot of good effects.

\subsection{The Results of the Interviews and the Discussions}

The interview aims at the outcome of the following aspects: the learning situation of students, the attitude of students towards the two different vocabulary teaching models and the evaluations of the students for the two teaching models.

When the first test was finished, the students of the two classes both said that the test paper is not difficult at all in the interview. As for the learning situation, the students in class A said that in flipped classroom they could learn the vocabulary before class by the video and they could write down the key words and key sentences. For the problems that the students could not understand by watching the video they asked the teacher for help and discussed the problems in groups. And the students could have a series of vocabulary activities to remember and internalize the words, which made them remember the vocabulary in class. However, the students in the traditional classroom said that although the teacher spent lots of time in explaining the words, it was more than boring and ineffective and they could not remember the words at all.

As for the attitude towards the two different vocabulary teaching model, the students in flipped classroom said they liked vocabulary teaching in flipped classroom very much. In flipped classroom, they were ready to the class and they were full of passion, which made them want to learn to win the activities in class. And during the process of activity in class they mastered the words already. Besides, the students thought vocabulary teaching in flipped classroom was effective and they could have more time to do the activities to master the vocabulary. The students all said they felt the changes in flipped classroom teaching model because they had to carefully prepare the vocabulary activities in order to win. However, the students of traditional classroom in the interview said they did not like the teaching model, which was time-consuming and boring, making students feel sleepy and lose interest in vocabulary learning. The class is teacher-centered and students have no choice to practice using vocabulary. Although the teacher spent lots of time in explaining the words, it was more than boring and ineffective and they could not remember the words. The teacher carefully explained the vocabulary in detail, the students felt rather boring and they could not concentrate on the class. The students spent lots of time in preparing the vocabulary ahead of class and the teacher spent a great deal of time in teaching the vocabulary, which was really time-consuming and ineffective. 
As for the viewpoints of the students towards the two different vocabulary teaching models, the students in flipped classroom said they hoped more in-class activities. The students thought the activity was really effective and interesting, which could help them master and internalize vocabulary knowledge in class. And the students hoped the teacher would continue to use this teaching model. While the students in traditional classroom said they did not like this vocabulary teaching model because it was ineffective and boring. The students hoped the teacher could give them half a chance to interact with him and they hoped they could have opportunity to practice the vocabulary in class, which also implies that vocabulary teaching in flipped classroom is effective than the traditional model. Flipped classroom provides a new way of transmitting knowledge before class and internalizing knowledge in class, which is more than effective.

\section{Conclusion}

In this paper, the researcher made a research of vocabulary teaching and through the research the researcher found some good effects of vocabulary teaching in flipped classroom. Flipped classroom changed the teaching method. Through the test and interview we have found that flipped classroom has some good effects in vocabulary teaching. Firstly, it improved classroom efficiency. For a long time, the explanation of vocabulary has been the focus on college English teaching, which often needs much in-class time. Teachers emphasized the importance of vocabulary output too much, ignoring students' ability of speaking, writing, and other language output. In addition, teachers can only teach a few words in limited time and the efficiency is low. Through flipped classroom, students can learn more words by themselves and they can put more time on language output. Secondly, the flipped classroom model can increase the students' interest in vocabulary learning. Flipped classroom enriches the content and method of vocabulary learning, improving learning interest of students. The traditional teaching method is single and boring, and the interaction between teachers and students is little, which cannot arouse the interest of students in learning. Through flipped classroom, teachers can use Internet, the mobile equipment and other resources to carefully prepare rich online materials to broaden vocabulary learning methods and channels, therefore, the student can adjust their learning process and allocate their time for studying vocabulary according to their actual situation. And in class, students can have all kinds of activities to apply the vocabulary and master the vocabulary, which is increasingly interesting and can arouse the learning interest of students. Thirdly, it can improve students' senses of learning achievements. Briefly speaking, with the flipped classroom model, it is possible that the students spend less time but achieve better outcome compared with the students from the traditional classroom.

Our research poses the real effects of vocabulary teaching in flipped classroom, which has a practical meaning in vocabulary teaching and learning. Besides, it provides a new method of vocabulary teaching and as a new teaching model, the advantage of flipped classroom is becoming recognized by more and more people. All in all, flipped classroom is a kind of teaching model that takes students as the center, which emphasizes students' personal study. However, in order to maximize its advantages in teaching, we still need to have further exploration of flipped classroom.

Of course, our research is not without limitations. First of all, the study only includes two classes of 62 students, a relatively small sample, which might not reflect the whole picture. Secondly, instruments used in the research are limited. The data collected in the study are only two tests and an interview. There may be some errors in the analysis. Thirdly, the research is not long enough for a further study so the results of the research may be unilateral. And the teaching of vocabulary in flipped classroom may have some shortcomings. For example, some students think the task is heavy. If the students cannot finish it, they will not participate in the class actively and the learning effect is not satisfactory. In addition, group activities in flipped classroom are usually carried out in the form of group. Students can internalize the new knowledge only when they take part in the class activities actively. If the group division of labor is not clear and students are not active in the group, the learning effect will be greatly reduced. Thus, adjustments and improvements should be made in future practice of flipped classroom.

\section{Acknowledgements}

Sincere appreciation must be given to all the people who have offered their supports to the research, especially the participants of the interview and the interviewer who has sacrificed a lot of time. This paper is one of the research results of The Research on the Localization Strategies of Flipped Classroom in Hebei Province College 
English Major's Teaching (2014YYJG268), which is a Hebei Province College English Teaching Reform Project launched in 2014. So, special gratitude is shown to Hebei Education Department.

\section{References}

Chen, X. (2014). A Study on Flip Classroom Teaching Model. M. D. Paper, Wuhan: Wuhan University.

Lents, N., \& Cifuentes, O. (2009). Web-Based Learning Enhancements: Video Lectures through Voice-Over PowerPoint in a Majors-Level Biology Course. Journal of College Science Teaching, 39, 38-46.

Richards, C. J. (2000). The Context of Language Teaching. Cambridge: Cambridge University Press.

Song, W. (2014). Application of Flipped Classroom to Vocational College English Teaching. Overseas English, $36,85$.

Strayer, J. F. (2012). How Learning in an Inverted Classroom Influences Cooperation, Innovation and Task Orientation. Learning Environments Research, 15, 171-193. http://dx.doi.org/10.1007/s10984-012-9108-4

Wilkins, D. A. (1972). Linguistics in Language Teaching. Cambridge: MFT Press.

Zhang, A. R. (2009). Vocabulary Teaching Strategies in College. Teacher, 52, 76-77.

\section{Submit or recommend next manuscript to SCIRP and we will provide best service for you:}

Accepting pre-submission inquiries through Email, Facebook, LinkedIn, Twitter, etc.

A wide selection of journals (inclusive of 9 subjects, more than 200 journals)

Providing 24-hour high-quality service

User-friendly online submission system

Fair and swift peer-review system

Efficient typesetting and proofreading procedure

Display of the result of downloads and visits, as well as the number of cited articles

Maximum dissemination of your research work

Submit your manuscript at: http://papersubmission.scirp.org/ 